\title{
Russian Timber Industry in the 1920s: \\ On the Short History of Russnorvegoles
}

\author{
JON LUNDESGAARD* \& VICTORIA V. TEVLINA ${ }^{\dagger}$ \\ *Faculty of Business Administration, Inland Norway University of Applied Sciences, Rena, \\ Norway \\ †Barents Institute, UiT - The Arctic University of Norway and Northern Arctic Federal \\ University, Archangelsk, Russia
}

ABSTRACT After the Russian Revolution, with civil war and interventions, war communism (1918-1921) led to a period of great economic difficulties in Russia. The New Economic Policy was the solution, and concessions offered to Western business interests were a part of $i t$. In the timber industry of the 1920s, the jointly Western and Soviet controlled company Russnorvegoles was an important concession. The majority of the Western interests were Norwegian, and the company was registered as a Norwegian limited liability company with seat in Oslo. The four-and-a-half-year history, involving Western interests in the operations of Russnorvegoles, is both interesting and dramatic. Profitability was undermined, and intricate currency arrangements played a significant role during the last eighteen months in which Western interests were involved. The prominent Norwegian fascist politicians Quisling and Prytz were both involved, and the latter emerged a wealthy man. Living on his means for some years following 1928, he contributed financially to the formation in 1933 of a Norwegian Nazi party (Nasjonal Samling/National Reunion). This dimension of Norwegian political history demonstrates the role that Russnorvegoles played beyond the timber industry.

KeY Words Timber industry, Northwest Russia, New Economic Policy, Severoles, Russnorvegoles concession, Quisling, Prytz.

Correspondence address: Jon Lundesgaard, Faculty of Business Administration, Inland Norway University of Applied Sciences, P.O. Box 104, NO-2451 Rena, Norway. E-mail: jon.lundesgaard@inn.no

\footnotetext{
* See correspondence address. Telephone + 4793042346

$\dagger$ Barents Institute, P.O. Box 107, NO-9915 Kirkenes, Norway. Telephone + 47918885 79, E-mail: victoria.tevlina@uit.no
} 


\section{Introduction}

Russnorvegoles was a joint Norwegian-Russian company established in 1923 to exploit the timber resources of northwest Russia. The history of Russnorvegoles is important for several reasons. First, the company was among the most important of the timber concessions, particularly in the North. Second, it throws light on the interaction between Soviet and Western interests in the 1920s, as powerful Bolsheviks developed what became known as the New Economic Policy (NEP). Thanks to fairly good access to Russian and other sources, it is possible to study this in some detail. Third, the history of Russnorvegoles reflects reactions to economic policy in the Soviet Union as it evolved at the time. Fourth, this timber concession involved a wide gallery of personalities who, for various reasons, are of historical interest. On the Western side, these include Frederik Prytz and Vidkun Quisling, who both later played a central role in the establishment and further development of the Norwegian Nazi movement. During World War II, Quisling headed the Nazi government brought into being by the Germans, and Prytz served as his minister of finance. Russnorvegoles played an important role in the early stages of this process.

Parts of the history of Russnorvegoles have over the years been subject to historical investigation. However, work done by others has generally lacked a focus on the history of the company itself, which thus remains incomplete. Typically, what we find are elements of company history included in work focusing on other areas - for example, the general Soviet concession policy of the 1920s, or the re-establishment of Norwegian-Russian diplomatic relations at the beginning of the 1920s. For this, see for instance Repnevskij and Zaretskaya (2006) and Repnevskij (1996, 1998). In addition, much of the literature on Quisling makes reference to Russnorvegoles and Prytz; see, for instance, Hans Fredrik Dahl's Quisling biography (Dahl 1991). 
More directly related to Russnorvegoles, work has been carried out by Yngve Astrup, Evgeny Ovsyankin and Andrej Repnevskij. The problem with their work is its incomplete treatment of the corporate history of Russnorvegoles. Astrup $(2011,2012)$ is not comprehensive, in particular on the second half of the company's history. Ovsyankin (1993) provides only a very short overview, and Repnevskij (1998, 2010, 2013) focuses mainly on other areas than the corporate history that we are interested in. ${ }^{1}$ Given the importance of Russnorvegoles indicated above, what we offer is a fuller history of the company. In particular, we provide a detailed account of the last two and a half years in which Western interests still played a role. Moreover, our more specific research ambition has been to clarify the complex currency arrangements in which the company involved itself.

In what follows, we make use of sources that have also been mined by others, but in a way that yields new insights into the history of Russnorvegoles. This is a result of our work with sources in both Russian and Norwegian archives, among others. Of particular use has been the archival material found in the Prytz Archive, placed in the National Archives of Norway. ${ }^{2}$

The history of Russnorvegoles is multifaceted, and it is therefore advisable to avoid too much detail. In framing our work as a corporate history, presented chronologically and without too many detours, we have pursued a traditional approach that we hope will clarify the short but complex history of Russnorvegoles. Following this Introduction, Section 2 includes a brief summary of the background required for understanding the establishment of Russnorvegoles, as presented in Section 3. In Sections 4 and 5, structural aspects of the company are discussed. Section 6 discusses the early emergence of problems with profitability, resulting in relations between Soviet and Western interests becoming more complicated and difficult. Russnorvegoles became entangled in the effects of the Soviet 
government's introduction, through a decree on 9 July 1926, of stricter currency

regulations, discussed in Section 7. In Section 8, we explain how Russnorvegoles tried to bypass these currency regulations. Section 9 explores the role of Quisling in the history of the company. In Sections 10 and 11 the reorganization of Western interests is examined, with the final Soviet takeover of the company. Finally, Section 12 gives an account of the way in which the liquidation of this joint Norwegian-Soviet company made Frederik Prytz a wealthy man, enabling him to establish himself as a Nazi leader in Norway.

\section{Background}

The Soviet Union was formally established on 30 December 1922, though it found its fuller, more stable political form around 1930. The October Revolution led first to a period of civil war and external intervention characterized by war communism, followed by a period of consolidation. Economically, war communism was a catastrophe, prompting the development of the New Economic Policy (NEP). Cross-border operations, going beyond what had been simpler market transactions, led to the establishment of joint ventures such as the Russnorvegoles concession.

The rich forest resources in the White Sea area were industrially exploited mainly from around 1880, when steam-driven frame-saws were introduced more generally. ${ }^{3}$ However, as Björklund (2000) points out, other factors also contributed to what became a booming expansion, in which entrepreneurs from abroad, including Norway, played an important part. ${ }^{4}$ In the late autumn of 1917 , with the October Revolution, history took a dramatic turn. However, in the White Sea area, centred in Archangelsk, the Bolsheviks were overthrown (see Goldin 1993, 2000a, 2000b). ${ }^{5}$ In addition, Abrahamsen (2015) gives a revealing account of Onega, located at the end of the Onega River, at the southern littoral of the White Sea. This work also includes an interesting account of the hardships involved 
in maintaining working sawmills. In February 1920, after a period of civil war (19181920) in which their opponents were supported by the Allies, the Bolsheviks took definitive control in the North. After a delay, the sawmills were nationalized.

In the history of Russnorvegoles, the Norwegian officer and businessman Frederik Prytz (1878-1945) was one of the most important figures. ${ }^{6}$ He arrived in Archangelsk in the second half of 1909, after having been on the lookout for some time for prospects other than those of an officer. What followed was his exceptionally rapid and successful establishment in the pre-revolutionary Russian timber industry. Following a short period as an employee, he started his own business. This led him to do business with a Londonbased Norwegian timber merchant, and to the formation of the Russia-based Prytz \& Co., as registered in Russian sources and pointed out by Tevlina (1994). In 1913, Union \& Co. joined Prytz \& Co., bringing in fresh capital. Union \& Co. was a major entity in the Norwegian timber industry, and the motive of the collaboration was to secure this company's timber supplies in Norway. In addition, the new partner was willing to engage in sawmill operations. After World War I had begun, a sawmill located in a northern district of central Archangelsk (Maimaksa) was taken over. In the spring of 1915 it burned down, but a rebuilt mill was in operation just under one year later. In 1916, Prytz \& Co. took over two sawmills in Onega.

In Norway, whose neutrality - enabling business to take place with both Allied and Central Powers parties - had led to a booming stock market, Prytz saw the possibilities that flotation could bring about. Prytz \& Co. became the Norway-based Russian Forest Industry (RFI)/Russisk Skogindustri. With Prytz as director, the new company was successfully floated in April 1917. Bringing in his interests from Prytz \& Co., Prytz received shares in the RFI. Most importantly, however, he also received cash amounting to more than twice the value of the RFI shares he received. In this transaction, a considerable 
part of what he had accumulated in Russia was safely, and miraculously, brought over to the West. In the protocols of the RFI it is clear that Prytz was able to engage a remarkable gallery of prominent personalities as business associates of the company. ${ }^{7}$ Among others, they included Elias C. Kiær (1863-1939), an account of whom can be found in Sogner (2001). Prytz played an important role in the events that followed.

\section{The Establishment of Russnorvegoles}

Of course, with the October Revolution the prospects of the RFI were fundamentally altered. Nevertheless, until the beginning of 1920 it remained possible to continue operations, under challenging conditions, with the help of among others, Egil Abrahamsen (1893-1979). He acted in various positions as close aide to Frederik Prytz. Abrahamsen (2015) provides an interesting account of this period, based on first-hand knowledge. In Norway, Prytz soon became an organizer of both the private Central Office for Norwegian Interests in Russia and the Norwegian-Russian Chamber of Commerce - that is, working actively for threatened Norwegian economic interests in Russia. ${ }^{8}$ This success led to a term as commercial attaché, from May to December 1918, in what was then Petrograd. Importantly for what was to come, this coincided with Quisling's appointment as military attaché in the same place. The acquaintance between the two men became a close, lifelong connection, and they partook in discussions of elements of what became their political orientations. A vivid account of their relationship is offered by Dahl (1991). ${ }^{9}$

In Norway, what followed for Prytz was a longer period of waiting and observation. As a central figure working for Norwegian interests in Russia, he was invited to participate as a delegate to international conferences. With the Bolsheviks in control, relations with Russia had to be settled. Prytz was able to make contact with prominent representatives on the Russian side, while also changing his position from one of making 
demands for compensation to one of adaptation to the new circumstances. The establishment of business relations with Bolshevik Russia raised the question of appropriate arrangements for the re-establishment of commercial relations, including contractual agreements on concessions. A typical arrangement was one in which companies constituted through cross-border partnership were granted concessional favours. That is, companies based in the West that were jointly controlled by Western and Russian interests.

In the summer of 1922, in combining their interests, the later Western owners of Russnorvegoles established an understanding of what was to come. ${ }^{10}$ In the autumn, a detailed declaration of intentions was signed between the Russian timber trust Severoles, represented by Semyon Lieberman (in the West, later Simon Liberman), and Western interests represented by Prytz. ${ }^{11}$ Lieberman (1881-1946) was, at the time, a Russian timber expert who wielded great political influence, as outlined in his memoir (Liberman 1945). ${ }^{12}$ He played an important role in establishing the State Timber Trust of the Northern White Sea District (Severoles) to administer the timber interests of the new regime in the White Sea area. ${ }^{13}$ Severoles was the first state trust established in the Soviet Union, and provided a model for later examples (Liberman 1945, 99). As president and managing director of Severoles, Danishevsky (1923) and Lieberman (1923), respectively, contributed with an optimistic picture of the company’s prospects. ${ }^{14}$ In addition, Lieberman referred positively to the prospects of mixed concession companies in general. Mixed timber concessions emerged with the formation of Russhollandoles, which had Altius \& Co. (the Dutch company later involved in Russnorvegoles) as Western partner, and with the formation of Russangloles, which incorporated the London \& Northern Trading Co. as its Western partner. The brothers Lipman and Mark Schalit controlled this London-based 
company. ${ }^{15}$ London \& Northern is of particular interest due to its important role during the final period of Russnorvegoles. According to Sutton (1968, 151-152), London \& Northern was formed on 20 September 1919 with an owner's capital of $£ 1$ million. According to historical accounts, this impressive amount originated from the proceeds of export sales before the Schalits were forced to flee Riga due to unrest caused by the October Revolution. After they encountered much trouble reaching London, their money awaited them at their London bank. ${ }^{16}$

During the summer of 1923, the Soviet government approbated the extensive concession contract for Russnorvegoles having as Western partner a majority of Norwegian interests. Formally, the contract was concluded with the Main Concession Committee, which was the organ established to oversee concessional agreements. ${ }^{17}$ The Russnorvegoles company was formally established in August as a Norwegian LLC/Ltd. (i.e. A/S) with constituent assembly and seat in Oslo (then Kristiania). ${ }^{18}$ In English, the company was named the Russo-Norwegian Onega Wood Company Ltd.

\section{Structural Factors}

Section 34 of the concession contract states that the concession was limited to twenty years, with the possibility of extension. Reflecting the types of activities they had in mind, the perspectives of the parties were long-term. Russnorvegoles was divided equally between the Western interests and Severoles - that is, according to the model adopted in forming Russangloles and Russhollandoles, with concessions in the White Sea area. At the time of its establishment, the distribution of interests among the Western parties was unstable. After a painful arbitration process, interests were equally divided among Houthandel vorheen Altius \& Co. of Amsterdam, Bache \& Vig/Bache \& Wager jointly (both seated in Drammen, Norway), and the RFI. It took some time to arrive at this 
arrangement, with the final agreement by all three parties being reached in the spring of 1925 , long after the formation of the company.

The shareholders' capital was stipulated in pounds sterling (British pounds), and set at $£ 300,000$. Accordingly, financial statements were worked out in pounds, as seen in Astrup (2011). The owners' capital was provided in kind as stocks that had been nationalized. ${ }^{19}$ In other words, the Western parties involved received 50 percent as compensation for nationalized stocks. What in modern accounting terminology would be plant, property and equipment (PPE) remained nationalized, and was placed at the disposal of Russnorvegoles on a rental basis. Quite favourably, this rent amounted to 0.5 percent of proceeds from sales. In Section 6 of the concession contract, a complex scheme based on stumpage fees determined what had to be paid for logs. Additional costs were attached to logging and floating timber, operating the sawmills, shipping, expenses associated with taxes, and more. Obviously, the presence of variable costs was more important than under more ordinary circumstances.

Russnorvegoles started out more or less without cash. According to Astrup (2011), the need for this was met with loans obtained in the City of London, from what seems to have been a medium-sized, respected merchant banking house - Wm. Brandt's Sons \& Co. - with which Prytz had established contact. It is clear from both Soviet and Western sources that Brandt's also acted as a sales agent for Russnorvegoles. The bank's activities were focused in Russia and Eastern Europe, including activities associated with the timber business. London \& Northern's later close contact with Russnorvegoles, and with Prytz, began with its contribution of an introduction to Brandt's, and with a loan guarantee against commission. $^{20}$

The board of Russnorvegoles consisted of eight members, four appointed by Severoles and four by the Western parties. The chairman was from Severoles, and Prytz 
was a natural candidate for the position of managing director. What he was paid over the years is not fully clear. In "[m]inutes from the board meeting (5 June 1926) and the general meeting (7 June 1926)", it is stated that the salary of the managing director was reduced and fixed at $£ 2,400$ per annum. In May 1928, it was said that the foreign managing director received the much larger sum of $£ 3,600 .^{21}$ When it came to opposing positions on corporate policy, it is clear that the governance structure adopted was rather fragile. As to the sorts of activity the company could engage in, the founding documents afforded Russnorvegoles generous freedom of movement. ${ }^{22}$ In understanding what motivated this, Albin (1989) is helpful in stating that concession contracts varied greatly in their stipulations, depending on what the Soviet side believed to be in its best interest.

\section{Operations and Profitability}

South of the small town of Onega were the forests Russnorvegoles was offered to exploit that is, forest plots of the Onega River basin, contractually fixed to roughly 2,900,000 desyatina, or 31,163 square kilometres, of which close to 70 percent was forestland. ${ }^{23}$ Geographically, the Onega River basin is considerably more extended. The concession was among the most significant ones, but it offered challenges as well as opportunities. According to Saitzev (1923), "The conditions of work in the forest district in the Onega basin, are, however, very unfavourable, especially with regard to the floating and the shipping of timber to foreign countries." Drifts would have to be cleared. Moreover, the port of Onega had to be deepened so that shipping became simpler, eliminating the need to use barges for the first stage of transportation. It was cheerfully assumed that this was something that could be solved by Russnorvegoles, which was soon to be formed.

In September 1923, according to Astrup $(2011,37)$, Prytz and others went to Onega to start work. What they encountered was characterized by Prytz $(1925,3)$ as "in a very 
unsatisfactory state." In addition, labour relations differed from what they were used to. ${ }^{24}$ Under the Soviet government, labour relations now included trade unions and complex regulations (see Abrahamsen 2015). After the end of concessions, Sutton (1968, 260) points out that this "was followed by the operation of the same northern lumber areas by prison [labour]". He also notes that this may have been going on before that, under concessional regimes still operating. ${ }^{25}$ In the forests upstream, nothing in our sources indicates, directly or indirectly, that Russnorvegoles had any involvement in forced labour. $^{26}$

For a business operating on its own, sufficient profitability is essential. After eighteen months of operations, Prytz (1925) reported that Russnorvegoles was massively unprofitable, representing more than a problem associated with the establishment and early stages of operations. He suggested that the company might have sustained a loss amounting to about 20 percent. That is, operating expenses exceeded revenues by about 20 percent. Prytz discussed factors such as sales prices, the exchange rate and productivity, and other factors determining costs of production, all of which contributed to this situation. In particular, the exchange rate fixed at the end of the monetary reform process, in May 1924, was seen as a problem. It is pointed out that " $[t]$ he high rate of exchange of the Tchervonetz [Chervonets] ... is not in any reasonable proportion to the purchasing power of the Tchervonetz in Russia." As a consequence of the monetary reform, a new rouble was introduced, making one Chervonets equal to 10 roubles. In Lundesgaard (2015), insights are offered into the factors presented by Prytz. Rescue as a possibility through better sales prices, or a more favourable exchange rate, were seen as less likely. The basic productivity of the workforce had been increased considerably, and was unlikely to be subject to further improvement without investment in fixed physical capital. Hence, Russnorvegoles was forced to address other factors determining costs of production - that 
is, factors ultimately redefined politically. The seriousness of the company's cash-flow problems, typically a consequence of insufficient profitability, was underlined by the halting of salary payments in the autumn of $1925 .^{27}$ In 1926 , this was exacerbated by the addition of further problems in meeting the company's obligations.

An obvious question is whether the involved parties, and in particular the Western ones, would have established the venture, given what Prytz (1925) reported. The terms for establishing Russnorvegoles were worked out over a short period, between the summers of 1922 and 1923. It was difficult to establish a clear economic picture of what was being planned. Moreover, given the booming expansion of the pre-war White Sea timber industry, in addition to the NEP heading towards more normal business conditions, it is likely that the problem of profitability was not examined intensively. On the other hand, some may have had their doubts. Interestingly, Lieberman (1923) stated: "Unfortunately, the cost of production per standard, (including stump payment), is higher than the corresponding figures of the Swedish timber exporters".

In his report, Prytz (1925) pointed out clearly that something had to be done. Otherwise, one had to realize that "the question of a final liquidation of our Company [has] to be considered." Lobbying was clearly required, now more directly addressing the complexities of Soviet politics. Already in the autumn of 1924, the central authorities in Moscow had been successfully approached on some issues relating to costs. But this was not enough: variable costs of export continued to exceed proceeds from sale. Leonid B. Krasin (1870-1926), people's commissar for foreign trade and a prominent Soviet diplomat, was approached jointly by Russangloles, Russhollandoles and Russnorvegoles, and presented in full with problems associated with profitability - first in a meeting with Krasin in Paris, and later in writing (see Prytz 1925, 4-6, including a letter to Krasin on 19 May 1925). Krasin had been a very prominent and influential Bolshevik from the start. ${ }^{28}$ 
At the time of the meeting, however, Liberman $(1945,168-169)$ was of the opinion that Krasin's political position was less secure. As is well-known, this was associated with the very demanding and time-consuming questions of both foreign and internal trade that were being addressed by Krasin. ${ }^{29}$

\section{Partners Drift Apart}

The NEP was introduced in a relatively clear and open manner, but its final stages were implemented differently. According to Nove (1989, 126), "official statements on the subject were ambiguous or deliberately misleading." In what follows, an account is offered of how this came about for Russnorvegoles. Krasin's involvement prompted him to send a short note on 1 June 1925 to the person he still believed to be the chairman of the Main Concession Committee, Georgy Pyatakov (1890-1937). ${ }^{30}$ The replacement was Leon Trotsky (1879-1940), who, before long, would lose his central position in Soviet politics. Despite this, he managed to stay at the head of the Concession Committee until October 1927, when he was succeeded by Vladimir Ksandrov.

Through its 50 percent ownership by Severoles, Russnorvegoles was in an indirect manner connected to Soviet authorities and to Soviet politics. Formally, however, Russnorvegoles was in a direct manner overseen by the Main Concession Committee. Soviet state trusts, such as Severoles, were overseen by the Supreme Council of the National Economy/VSNKh/Vesenkha. ${ }^{31}$ Felix Dzerzhinsky led the VSNKh from February 1924 until his dramatic death during a meeting on 20 July 1926. According to Graziosi (1991) he died while attacking Pyatakov. This role of Dzerzhinsky was combined with what he was most well known for: being the intimidating chief of the Cheka/GPU/OGPU (the names successively taken by the secret police under his command). Liberman (1945) offers an account, based on his personal experience, of how the secret police was active 
through its economic section with special economic monitoring functions. Dzerzhinsky was succeeded as head of the VSNKh by Valerian Kuybyshev (1888-1935), who sided with Stalin in distancing himself from Trotsky, just as Dzerzhinsky had.

In this section, we take a closer look at events following the process of establishing Russnorvegoles. The complexity of this process reflects several complicated and interconnected circumstances that were about to arise. First, as hinted at above, these had to do with Soviet politics and institutional arrangements. Second, probably on the direct personal initiative of managing director Prytz, Russnorvegoles was about to take action in more politically sensitive directions, including changing its ways of doing business. In all this, the role of the Main Concession Committee in overseeing Russnorvegoles was important. In relation to this, one problem is that, as far as we are aware, a comprehensive and scientifically researched history of this institution has yet to be presented.

From Prytz (1925), it is clear that something had to be done. The first outcome was a surprising swing in the company's sales towards the domestic Soviet market. At the same time, it urged the Main Concession Committee to alleviate working conditions through an amendment to the initial concession contract. The important role that the Soviet market played in 1926 is well documented. According to Abrahamsen (2015), in 1926 three big ships loaded with sawn goods were sent around Europe to the Black Sea. Moreover, Benjamin Vogt $(1965,1966)$ reports on how he was sent to oversee unloading. ${ }^{32}$ The destinations included Odessa, Myklaiv/Nikolaev and Mariupol. Parts of these shipments were redirected to Batum because of a devastating earthquake. It is said that the Black Sea shipments amounted to 5,500 standards, later corrected to 5,045 standards. These shipments were minor parts of the project of turning to the domestic market. It is said that 18,000 standards were shipped through Kem (a station on the 
Murmansk line) and through Archangelsk, this later was corrected to 14,227 standards. ${ }^{33}$ We are left with the question of what motivated this massive move away from exports. Serving the domestic market was less unprofitable - even profitable. The Shalakusha mill, operating from August 1927, was a strategic investment in serving the domestic market. ${ }^{34}$ On the railway line to Archangelsk, Shalakusha is situated about two-thirds of the way from Vologda, on the Mosha River, an eastern tributary of the Onega River, with much forestland upstream.

Jungar $(1974,170)$ includes an odd series of pound-sterling proceeds from export activities of Russnorvegoles. The figures Jungar includes are based on two sources: Swedish diplomatic correspondence for 1924 and 1925, and Butkovsky (1928) for subsequent years. For each year of shipping, sterling proceeds from exports were as follows: $£ 450,000$ (1924); £450,000 (1925); £116,000 (1926); £262,000 (1927); and $£ 490,000$ (1928). Compared to the first two years, the decline in exports in 1926 is close to 75 percent, and in 1927 almost 40 percent. These figures are proceeds in the West from exporting, minus what was needed to meet obligations in the West. This included costs starting when goods meant for sale in the West were loaded on board ships in Onega. This difference was what returned, or should return, to the Soviet Union in foreign currency (the sterling proceeds from exports). Alternatively, these amounts can be seen as what Russnorvegoles officially, against foreign currency, bought of roubles in the Soviet Union. Given the prices of goods sold in England calculated in Lundesgaard (2015), reductions in volume were not that far from what is reflected in the above in percentages. By 1928, the year Russnorvegoles was taken over by Severoles, the export figure had recovered to a little more than where it had begun. The domestic sales effort of Russnorvegoles may well explain most of what is missing in Jungar's 1926 figure. In addition, we are left with the question of how to explain the 
1927 figure, which we address in later sections.

Addressing the Main Concession Committee was a lengthy process. In August 1925, the Western owners of Russnorvegoles formally approached the committee with the problems of profitability and how to address working conditions. On 17 December 1925, the committee arrived at conditions that it saw as sufficient to bring about balance in the income statement. ${ }^{35}$ However, formal approval was delayed for several months. This led the Western owners of Russangloles and Russhollandoles to sell their shares to the Soviets (Severoles) for about 20 percent of their nominal value. Prytz $(1925,6)$ notes that, under the circumstances, "our chance of obtaining financial assistance in London for the continuation of our operations in Russia will be a very remote one.” In fact, for 19251926, the operations of Russnorvegoles operated very much on a hand-to-mouth basis.

In one-way or another, an amendment to the first concession agreement had to be added. An important part of this process included negotiations in May 1926, held in Moscow. Russangloles and Russhollandoles were no longer involved at this point. Interestingly, the later-prominent Annæus Schjødt Sr. (1888-1972) was brought to Moscow by Russnorvegoles. ${ }^{36}$ Following the May 1926 negotiations, Russnorvegoles formally employed Quisling in July $1926 .{ }^{37}$ The presence of Schjødt was probably not intimately related to the negotiations with the Main Concession Committee. Talks were taking place in parallel with Severoles over a complex legal dispute in which Schjødt was acting as legal counsel for Russnorvegoles. ${ }^{38}$

The results of the May 1926 negotiations are to be found in a letter of 28 May 1926 from the Main Concession Committee. ${ }^{39}$ Specifying that they applied to exported products only, allowances were offered that were said to end on 3 July 1928 . The contributions to reduced costs were substantial, nevertheless. The stated obligation of Russnorvegoles was that at least 50 percent of output went to exports. In addition, 
adequate financing had to be secured, and shareholders' capital had to be increased. The financial obligations vis-à-vis Soviet institutions had to be settled as soon as the agreement was in effect. The matter-of-fact comment of the managing director was that he was going to present all this to Western parties and "take up negotiations." This process was crowned with success when Wm. Brandt's Sons \& Co. finally proved willing to grant credit in the amount of $£ 520,000 .{ }^{40}$ On 28 September 1926, the Main Concession Committee and the involved Western parties formally concluded the agreement. ${ }^{41}$ What was finally offered and approved by the Soviet government on 9 November 1926, however, had been altered. The end-result included both negative and positive elements, though the former outweighed the latter. ${ }^{42}$

Somewhat surprisingly, early in the process of negotiation with the Concession Committee, the question was raised of a more fundamental redesign of the concession agreement. What was proposed was a conversion of Russnorvegoles into a "pure concession" - that is, a concession granted to a wholly Western-controlled company, referred to by Sutton $(1968,7-8)$ as a Type I concession. For Russnorvegoles, this meant that 50 percent of shareholders' capital, held by Severoles, was to be taken over by Western interests. In the understanding of 1926, this issue was not concluded, but remained open to further discussion. One may wonder what the motives of the parties were. Nevertheless, this was something the Main Concession Committee was willing to discuss. From the Western perspective, this may have been a way to put pressure on Severoles. In addition, with Severoles out of the way, the company's governance processes and its contact with the Main Concession Committee would have been simpler.

From the second half of 1925, relations between the Eastern and Western owners of Russnorvegoles began to deteriorate. It is registered that this coincided with 
Betchin joining the board. Later, from 8-9 June 1926 onwards, he advanced to the position of chairman. Soviet board members and employees with good and confident relations with the Western leader were discharged; relations ended in open conflict. This can be clearly seen in the correspondence between chairman Betchin and managing director Prytz in February-March $1927 .{ }^{43}$ Abrahamsen (2015) offers many accounts of how Soviet interests were met in leading to something productive. Between the end of 1926 and the beginning of 1927, this turned out to be more difficult. This observation of Abrahamsen fits well with the Betchin-Prytz conflict.

For Russnorvegoles, 1926 was a demanding year for several reasons. In addition to the problems outlined above, various opinions were advanced on how to approach markets in the West. Russnorvegoles opted to take advantage of the established market organization by, for example, including intermediary agents. Severoles believed in approaching the demand side more directly by taking advantage of supply-side market power. The change in direction of the domestic market led to optimism, and Prytz pointed to the possibility of "being able to show some - even if slight - profit in our next Balance Sheet." 44 The miserable financial situation of Russnorvegoles led to the late payment of sums due to local authorities, and to the obstruction of operations. ${ }^{45}$ As a result, the financial year ending on 31 October 1926 was concluded with a loss. ${ }^{46}$

\section{Currency Regulation - Quisling and the Roubles}

From entries of November-December 1927 in the diary of Wager, it is clear that the Soviet side was starting to show interest in how Russnorvegoles dealt with currency issues. This led to a series of meetings on the subject, in which the Main Concession Committee and its deputy chairman Reichel participated. ${ }^{47}$ The seriousness of what was discussed is attested by the fact that Prytz, on Saturday, 17 December, was denied an exit visa - though a 
successful appeal was pursued. On Monday the initial decision was reversed, and the day after that Prytz left Russia for what would be the last time. As is pointed out by Astrup (2011), even now the critical substance of the currency issue remains unclear. A solution to this problem is hindered by a poverty of empirical information on the episode. Russian sources, meanwhile, have tended to be vague. However, help is to be found in the Prytz Archive. Before reporting its results, however, more background is needed.

The Soviet Union's healthy financial position at the beginning of 1925 indicated the success of the monetary reform process. One year later, as a result of an overambitious economic policy, this was no longer the case. Through a fractious and complex political process, the instituted NEP order faced a challenge. As a result of this, in the spring of 1926, the holding and use of foreign currency in the Soviet Union was made subject to more aggressive regulation. The market-based exchange of currency within the Soviet Union was thereby hindered. Under the established regime, Chervonets roubles (the new rouble) were allowed to be exported. What was exported was then bought back from abroad by the Gosbank at the official exchange rate. Most importantly, on 9 July 1926 this was banned by a decree of central Soviet authorities. In addition to Carr's (1958) Chapter 9, Goland (1994) is a very insightful reference. The exchange rate adopted as a result of the monetary reform favoured imports by creating massive incentives in the direction of launching import projects. In licensing, it was the task of foreign trade authorities to ration the flow of imports, and thus limit the outflow of foreign currency. The licensing system included two rounds. After a first round of licensing by foreign trade authorities, deals were finalized in a second round of licensing by an authority established for the purpose that is, the licencing of transfers for the settlement of obligations between internal and external counterparties. ${ }^{48}$ The measures taken, ending with the decree of 9 July 1926, were less critical for deals already underway in the double-licencing system for imports. 
However, this system had not been fully implemented, raising the question of what would happen with deals outside the double-licencing system.

What else has been said about the currency arrangements of Russnorvegoles? Returning to the early 1930s, this is part of the Quisling literature. Quisling's private and political life is associated with several peculiar episodes. One is that, during his Moscow period (1926-1929), working first for Prytz and subsequently for the Norwegian foreign office, he was involved in a number of dubious currency transactions. Oddvar K. Høidal is one of two academic authors who have presented extensive work on Quisling. Referring to Vogt (1965), Høidal $(1989,37)$ introduces this episode by noting:

In order to get around their [i.e. Soviet] currency restrictions, [Prytz] proceeded to purchase [roubles] in the black market, which enabled him to meet the company's obligations in the Soviet Union much less expensively than if he had dealt through the official Gosbank. His intermediary in these transactions was Quisling, who exchanged foreign currency, mainly British pounds, in return for black market [roubles].

The other author is Hans Fredrik Dahl, whose treatment diverges from Høidal's. First, Dahl judges some sources to be contradictory, and thus relatively unreliable. Second, he points to the unlikeliness of an engagement by Prytz in transactions that might have ruined his reputation. Third, he introduces a new source - namely, four of Quisling's cheque books, dated 1926-1929, with cheque stubs including relevant notes and on the reverse of the books a running record of the account's rouble position. ${ }^{49}$ Rather than seeing these payments as pointing in the direction of less legitimate transactions, Dahl views them as transactions relating to the ordinary company accounts of Russnorvegoles.

Almost in parallel, two prominent Quisling scholars offer differing versions of what is often referred to as the "Quisling rouble scandal." For Dahl (1991), this alleged scandal is all based on hearsay, and evaporates when examined more deeply. Høidal is clearly unimpressed by Dahl's interpretation. He repeated his own version on television on 
9 December 2002, without mentioning Dahl. They are both wrong: Høidal's account is in contradiction with documentary evidence, while Dahl overlooks the existence of more sophisticated currency arrangements whose effects are of historical interest.

\section{Bypassing the Decree of 9 July 1926}

The concession contract granted Russnorvegoles considerable freedom when it came to the purchase and import of roubles. ${ }^{50}$ The decree of 9 July 1926 about the export of roubles was concerned with regulating their more or less free export - an activity Russnorvegoles was not typically involved in. Hence, it is not immediately obvious how the company was brought into a position that prompted accusations of its having violated the decree. By operating through the Berlin bank of Bernheim Blum \& Co. from the autumn of 1926, Russnorvegoles changed its method of purchasing roubles. In a telegram from Reichel of the Main Concession Committee - in a statement that was also included in a telegram of 15 February 1928 from Prytz to London \& Northern - it was asserted that the Bernheim Blum \& Co. arrangement was contrary to Soviet law, and thus had to be terminated. ${ }^{51}$

Russnorvegoles concluded two contracts with Bernheim Blum \& Co., both dated 11 October $1926 .^{52}$ The first, on currency transactions, stated that the Berlin bank would sell the roubles required at the official exchange rate against sterling, with up to $£ 50,000$ in uncovered amounts. In the second agreement, credit of $£ 100,000$ was offered. Obviously, in exchange for roubles, the Berlin bank did not bring foreign currency into the Soviet Union that was credited to the foreign currency account of the Gosbank. Something was on offer that differed from normal practice. Inside the Soviet Union, an easily available alternative was to acquire rouble obligations paid for in the West, which in due course yielded a return in roubles. This implies the set of relationships outlined in Figure 1. 
Transactions with "other parties" were most likely effected at the official exchange rate. Bernheim Blum \& Co. was compensated based on commissions.

\section{Figure 1 here}

The complementarity between the types of transactions represented at the top and bottom of Figure 1 is obvious. In reality, Russnorvegoles contributed to those "other parties" being able to convert roubles_into cash such as pounds in the West - in particular, as noted by Reichel of the Main Concession Committee, through bypassing the rouble export ban. In due course, rouble cash was traded inside the Soviet Union and kept track of, as indicated by the dotted half-circle. The move from London to Berlin, taking advantage of the services of Bernheim Blum \& Co., was probably a function of the extensive network of connections of the Berlin bank with banks inside the Soviet Union.

In the Prytz Archive, a summary can be found (undated) of Bernheim Blum \& Co.'s rouble transactions on behalf of Russnorvegoles. The transfers of roubles began in October 1926, and ended in December 1927. Settlements in pounds began in November 1926 and ended in February 1928. The total amount of roubles transferred was 7,677,461, bought for $£ 814,435$, using an exchange rate starting at 940 roubles per $£ 100$, and ending at 944.50 - that is, at what seemingly was the official exchange rate. What is presented above, in Section 6, as missing in the Jungar's 1927 figure $(1974,170)$ is fairly well explained by this arrangement with Bernheim Blum \& Co.

The arrangement was such that, sooner or later, it would become clear that Russnorvegoles was far from contributing with foreign currency, as it would normally have had to. In concentrating on what is depicted in the upper part of Figure 1, Prytz played this down, arguing that the arrangement conformed with the terms given in Section 
13 of the concession contract. Most interestingly, those referred to as "other parties" were offered a favour in being able to convert roubles to pounds. This prompts the question of how the party who made all of this possible (Prytz) was included, and thus compensated. Our sources are less than fully clear; in proceeding, it is helpful to separate the currency issue as three sub-problems: first, the problem of what happened and its economic implications, such as those outlined above; second, the question of who the "other parties" were (discussed immediately below); and third, the problem of transfers between the parties involved. Since it is related to how the Western interests involved in Russnorvegoles were restructured, this last problem is discussed in subsequent sections. In Astrup (2011, 44), it is stated that (here rendered in translation) "the involvement was likely of Western businessmen who were owners of rouble obligations they were unable to escape. [Here in footnote 77 it adds: Frederik Prytz' daughter Bibi Huitfeldt has this version from her father, who said that Brandt's initiated the arrangement.] Locked-in rouble obligations were favourably bought up by somebody who could collect and use the roubles in Russia." It is clear that the arrangement with Bernheim Blum \& Co. made it unnecessary for the buyer, Russnorvegoles, to establish direct contact with the seller or sellers. In the accounts of Russnorvegoles, the Berlin bank was named as the other transacting party.

Pointing to a question related to the currency issue, Vogt $(1966,88-93)$ remarks on Soviet bills of exchange drafted in England. ${ }^{53}$ These bills were typically "long", offering generous credit of up to one year. Bills were sold and bought at up to 25 percent less than their nominal pound value, paid on maturity. That is, settlement risks were regarded as considerable, most likely due to Soviet currency regulations. In approaching the Russian importer/bill drawee to pay in roubles in a specified manner inside the Soviet Union, any loss due to default in pounds was avoided. In addition to this, less expensive roubles were 
eventually made available. These would all have been areas in which the assistance of Bernheim Blum \& Co. could have proved helpful. As to the "other parties" identified in the illustration above, Astrup $(2011,44)$ notes that "[ $\mathrm{t}]$ he Western businessmen mentioned could have been London \& Northern Trading Co., who most probably owned the rouble obligations sold to Russnorvegoles." ${ }^{, 54}$ Pointing in the same direction is the observation by Vogt $(1966,91)$ that the Schalit brothers of London \& Northern were active in Soviet bills of exchange.

\section{The Role of Quisling}

Prytz "offered [Quisling] the position as the Company’s representative in Moscow." Chairman Betchin opposed this, and obstructed Quisling's appointment. The duration of his engagement for Russnorvegoles was less than one year. The Arcos affair of May 1927 led to the severing of diplomatic relations between the Soviet Union and Great Britain; Norway thereafter represented British interests in Moscow. ${ }^{56}$ More people were needed, and this led to Quisling's engagement of 14 June 1927 with the Norwegian diplomatic mission in Moscow. ${ }^{57}$ It is not clear that Quisling played a direct role in the arrangement with Bernheim Blum \& Co.

Nevertheless, the received account attributes to Quisling a role in the rouble deals of Prytz and Russnorvegoles - though what this amounts to remains less than fully clear. Engaging in cross-border and black-market operations, as alluded to in the Quisling literature, is clearly something that is less likely. Most probably, what Quisling contributed went through the Gosbank checking accounts that he administered. An analysis of the cheque books leads to the following observations. First, a Gosbank checking account (account no. 7356) was first opened at about the same time as the initiation of the Bernheim Blum \& Co. arrangement. Second, most of what is remitted was parallel to this 
arrangement, calculated at about 24 percent of the arrangement - that is, a significant rouble amount in total. Third, the source is silent about where the roubles came from. Fourth, some cheques have the appearance of bonus payments. ${ }^{58}$ Given Russnorvegoles's critical financial position, in addition to Prytz's difficult relations with the Soviet owner, it is less likely that bonuses could have been granted using the official method. This points to the possibility of an "extraordinary rouble chest" - that is, something other than an ordinary company account inferred by Dahl (1991, 129-131). Fifth, being a company account, it should have been liquidated at some point, and the remaining balance transferred back to Russnorvegoles. Sixth, roubles were paid in and transferred as before after the engagement of Quisling as a diplomat.

Most significantly, it is also recorded that cheques were drawn to "ego" (Quisling himself). These payments amount to the impressive total of 16,000 roubles - roughly equivalent to three years or more very good salaries in Norway. From the end of 1927 to 4 November 1929, cheques were drawn more and more often to "ego", and in increasing amounts. Quisling came home from Russia well furnished with art objects and furniture. Dahl (1991) provides photographs of the grandiose interiors of his Oslo residence. This is how a generous rouble bonus was repatriated to Norway.

\section{Towards the End: The Restructuring of Western Interests}

Year 1927 saw a swing back to exports, even though this is not reflected in the figures reported by Jungar $(1974,170)$ for this year. ${ }^{59}$ In addition, 1927 was the last full year in which the Western owners were involved in Russnorvegoles. Before this point, Western interests were restructured.

In the spring of 1917, the RFI seemed promising. The standard owner's capital of 8,000 shares at 1,000 kroner per share was more than fully subscribed. Preference shares 
up to 3,000 shares, at 1,000 kroner per share, were issued around the turn of 1918/19. A subscription of 1,277 shares indicated that prospects were less than promising. ${ }^{60}$ In fact, the RFI never contributed dividends, and the engagement in Russnorvegoles did not provide a return. In addition, the RFI's Norwegian bank was on occasion forced to come up with favourable arrangements, so as to avoid bankruptcy. Around the turn of 1926/27, the patience of what was then Andresens og Bergens Kreditbank was finally exhausted. The restructuring of loans led to a total debt of 1,681,596.19 kroner, equivalent to about $£ 88,500$ - an obligation the RFI was not able to sustain. Worth much less than this, and in any case difficult to sell, the RFI's main asset was its shares in Russnorvegoles. At the beginning of January 1927, help came from London \& Northern in a deal it concluded with the RFI and the bank. ${ }^{61}$ London \& Northern paid $£ 17,000$ to assume the bank's claim on the RFI. In addition, $£ 2,500$ was transferred from the bank to the RFI, enabling the company to keep going. The net of the bank was $£ 14,500$, and a considerable loss had to be written off. One year later, London \& Northern bought the RFI's shares in Russnorvegoles for $£ 15,000 .^{62}$ That is, for 30 percent of its nominal value, instead of the roughly 20 percent that had been received by Russangloles and Russhollandoles in 1926. In the liquidation of the RFI, London \& Northern's claim on the company was "forgotten", and the RFI's shareholders ended up with 240,000 kroner: 2.6 percent of their initial investments. Developments between the RFI and Russnorvegoles, as they unfolded, must have compromised Prytz's reputation as an industrialist and businessman. Obviously, part of the net profit that resulted from the cooperation between London \& Northern and Prytz was used to render the end of the RFI less bitter.

Part of the net amount accumulated from the currency arrangement was transferred to Prytz in person. That is, by an arrangement in which cash finally went from London \& Northern to Prytz personally. In this arrangement, Prytz at a favourable price bought up 
Western-owned shares in Russnorvegoles and then sold them at a much higher price to London \& Northern. In correspondence between London \& Northern and Prytz in the Prytz Archive, this is a clearly documented case on two occasions. The shares bought and after that sold by Prytz, were typically held in his name until further notice from London \& Northern. First, in a letter from London \& Northern to Prytz dated 17 December 1926, he was asked to confirm the payment for 14,000 shares, based on the nominal value of $£ 1$ per share. Part of the deal was an earlier loan received from London \& Northern, amounting to close to 40 percent of the nominal value of what was bought. This was probably what Prytz paid, and what was needed to buy the shares. In calculating interest, Prytz's net profit was $£ 7,770$, at the time equivalent to 149,000 kroner. An option of London \& Northern was included, documented in a handwritten copy of a letter of confirmation by Prytz on 21 December 1926, offering London \& Northern the opportunity to buy another 10,000 shares at their nominal value. The first 14,000 shares, plus the 10,000 shares of the option, were said to come from Bache \& Vig, of Drammen, with 1,000 shares reserved for Jens Vig. It is not documented whether or not the option was exercised.

Second, in a letter from London \& Northern to Prytz dated 13 January 1927, it is confirmed that 30,000 shares were bought by London \& Northern at $£ 18,000-60$ percent of their nominal value. Assuming these were acquired by Prytz at 40 percent, his net profit was $£ 6,000$ pounds (about 113,870 kroner), and at 30 percent his profit would have been $£ 9,000$ (about 170,800 kroner). In a letter from London \& Northern to Prytz dated 30 November 1927, Prytz was asked to confirm settlements received in the total amount of $£ 18,000$, plus $£ 768$ and 15 shillings for expenses covered. The general assembly of Russnorvegoles was held on 10 March 1927, with Drammen's interests absent - indicating that they must have been bought out in full. ${ }^{63}$ Prytz took part both as a representative of the 
RFI and as a shareholder in person. This suggests Prytz would have been able to buy, and London \& Northern to sell, more shares than are clearly documented in the Prytz Archive.

\section{The Soviet Takeover}

As we have seen, the renegotiated concessionary arrangement ended on 3 July 1928. Around the turn of $1927 / 28$, various options appeared to be available: first, converting to a purely foreign-owned concession; second, remaining, as up to this point, a mixed concession, subject to renegotiation; and third, incorporating foreign interests into Severoles. At the beginning of 1928, partly as a result of what had surfaced in relation to currency arrangements, the Soviets were in favour of the third option (see Zagorulko 2005, 360), based on a Main Concession Committee report. ${ }^{64}$ Both Russian and Norwegian sources contribute to our understanding of what then took place. At the beginning of the year, a meeting between Eastern and Western parties was planned, and convened in Berlin on 15 April. Close to eighteen months after this, Prytz, confirming his presence at the meeting stated: "I am aware that you [the Schalits of London \& Northern] as representing the 'Foreign Group' originally demanded about $£ 30,000$ for the 127,500 shares in question, but that you could not make Severoles pay more than $£ 18,000$ cash." ${ }^{, 65}$ What was demanded was 23.5 percent of the nominal value; but what Severoles paid was 14.1 percent. For the selling party, this was a depressing result.

At the board meeting on 8 May 1928, the only Westerner represented was Dutch Koopman, who still held some interests in Russnorvegoles. ${ }^{66}$ Prytz and others were discharged. From Abrahamsen (2015) and other sources, it is known that the Oslo office was soon closed and operations in the West moved to London, with Yakov Aksenov as managing director. Aksenov brought Egil Abrahamsen with him as his assistant. From 1 August 1928, the shares of Russnorvegoles were fully under the control of Severoles. ${ }^{67}$ 
According to Abrahamsen, his engagement ended some time in 1930; after that, he began work for the timber department of Wm. Brandt's Sons \& Co., in London.

\section{Epilogue: Norwegian Political History}

On Frederik Prytz, Andrej Repnevskij observes that, in having passed away shortly before the end of World War II, he ended his life with a total political and moral collapse. On the other hand, Repnevskij $(2010,123)$ also writes that "Prytz made a significant contribution to the development and to the restoration of the forest industry of the Arkhangelsk region as an entrepreneur." In other words, he is full of approval and praise. What we have attempted to do here is add a balancing element to his account. Moreover, the two sides of Prytz's character that Repnevskij highlights are closely interconnected.

The Russnorvegoles project ended by significantly enriching Prytz. How much this final bequest exceeded his generous salary is not fully clear. Nevertheless, it was enough for Prytz to live for five years without working, though he remained active as a private investor. His investments yielded varied success, echoing his experience with the sum he had had been able to bring home to Norway in 1917. Moreover, he engaged energetically in right-wing politics, as touched upon by Nielsen and Tevlina (2014). At the end of 1929, Quisling returned from Moscow and - according to Caroline Prytz - told Prytz that the time had come for them to enter into joint political work along the lines they had discussed in Petrograd in 1918. With Quisling as a figurehead and with Prytz as an organizer behind the scenes, this project was embarked upon through the establishment of a certain position in Bondepartiet (the agrarian party) and through other means. Prytz's strong financial position was an indispensable aspect of this endeavour.

In parallel, based on their strong connections in general staff circles, involving some centrally placed officers, they planned a pre-emptive military coup d'état. This fitted 
well with their belief in an authoritarian, fascist political regime, and is firmly documented by Borgersrud (2010). ${ }^{68}$ The Bondepartiet formed and rose to power between May 1931 and March 1933, producing a government with Quisling as minister of defence. This was nothing less than a remarkable achievement. However, for want of both the opportunity and the nerve, what had been planned was not ultimately carried out. Relations with the Bondepartiet cooled, and in May 1933 Quisling and Prytz formally established the Nazi party, Nasjonal Samling (National Reunion). It is said that, without Prytz, there would have been no Quisling. It might well be added that, without the means that Prytz had accrued from Russnorvegoles, Quisling and Prytz would not so easily have asserted themselves in Norwegian political history.

\section{Acknowledgements}

We are grateful for the financial support of Hedmark University College, now part of the Inland Norway University, in our archival research in Russia and elsewhere. We thank Yngve Astrup for providing generous and helpful access to all kinds of source material that he has himself taken advantage of. Discussions with Lars Borgersrud and Jens Petter Nielsen were very useful. Finally, comments of two anonymous reviewers and the editors of Acta Borealia have made an indispensable contribution to the end product.

\section{Notes}


1. Repnevskij (2013) is a comment on Astrup (2011) containing both praise and harsh criticism. Astrup is praised for having identified interesting sources. At the same time, he is criticized for a clearly unbalanced presentation of historical aspects of the timber industry in the North.

2. Archive PA-0749 (Prytz Archive) of the National Archives of Norway (documents donated on 24 February 1989) is extensive and disorderly. This has obviously represented a problem for researchers. Without having an actual copy of what is relevant for the problem under investigation - such as, in our case, about 300 pages copied electronically - it is difficult and very time-consuming to take full advantage of the archive.

3. Repnevskij (2013), in referring to the work of Ovsyankin, points to industrially organized activities that took place long before that.

4. Astrup (2011) points out that, in 1917, roughly nine out of forty sawmills in the area were in Norwegian hands. Tevlina (1994) reports that, in the Arkhangelsk province, about twenty large timber industry companies had been founded by foreigners - that is, close to half of the sawmills (forty-four) operating in 1917. Eleven Norwegians owned sixteen or seventeen sawmills. In one rare case, ownership was Russian-Norwegian. For added details, see also Björklund (2000).

5. Kotsonis (1992) is of interest for the interregnum in the North - as, in a very different way, is Fraser (1984).

6. The importance of Prytz is underlined by the interest shown in him in Russia, such as by Repnevskij (2010).

7. Seen in the protocols of the organs of the RFI in the National Archives of Norway. Sølverud (1992) offers an analysis of the initial subscribing shareholders of the RFI. 
8. For details on Prytz and the Central Office, see Nielsen \& Tevlina (2014, 516$518)$.

9. This is the first of two volumes on Quisling. In 1999 they were reduced to a single volume and published in English.

10. See "Agreement" of 6 June 1922 in Christoffer Vig's Private Archive.

11. See "Declaration of Intentions" of 21 October 1922 in Christoffer Vig's Private Archive.

12. These memoirs offer a vivid account of certain parts of the interesting life of Lieberman. Prytz ("Prits") is mentioned on three occasions. His stepgranddaughter, Plessix Gray (2005), includes supplementary biographical information. After being sent to the West early in 1926, Lieberman decided to stay.

13. According to Jungar (1974, 162-163), Severoles was established on 17 August 1921.

14. Both articles were published in "Severoles," a company journal named after the company itself. Previously, Karl Danishevsky had been in charge of resolutely disciplining officers and soldiers of the Red Army. According to Liberman (1945, 85), even if his prospects were not that good, Danishevsky did well, and after meeting with Stalin he told friends: "Stalin has forgiven me." As clear from “London \& Northern Trading Co. (1929-1932): Documents Related to Legal Proceedings with Arcos as the Other Party," he continued to work in the timber business. Documents in the private archive of Mike Shalit, Israel, which are our only written source originating directly from London \& Northern.

15. Mark (Morduch) Schalit died in 1935 (see "Financial Times," 26 February 1935) and Lipman Schalit in 1939 (see "Financial Times," 9 February 1939). Mark is referred to as managing director and Lipman as chairman (former). Hardy (2004, 
352), referring to a letter from 1940 , says that London \& Northern finally collapsed sometime in the 1930s. The Schalits and their business were related to Isaiah Berlin (1909-1997) and his family.

16. From contact with descendants of the Schalit brothers.

17. See "Concession Contract" of Russnorvegoles in Christoffer Vig's Private Archive. Contract sanctioned by the Main Concession Committee on 5 May 1923 and approbated by the Council of People's Commissars (Sovnarkom) on 3 July 1923.

18. See protocol from the general meeting on 11 August 1923 and Articles of Association approbated at the same meeting. Both in Christoffer Vig's Private Archive.

19. See protocol from the general meeting on 11 August 1923 where it is stated that "the Company [is] taking over stocks to an estimated value of $£ 300,000$." Christoffer Vig's Private Archive

20. See draft or copy of a letter of spring 1924 from Prytz to London \& Northern, in the National Archives of Norway, Prytz Archive.

21. For "minutes", see the Prytz Archive, in addition to RGAE Fond 7758, op. 1, d. 73, p. $78-79$ a. Prytz was very well paid, in a sum amounting to about 60,000 or 70,000 kroner. According to Westlie (2015), the general director of the State Railways was paid 33,000 kroner plus extras in the second half of the 1930s.

22. In particular, see Sections 9-14 of the "Concession Contract" of Russnorvegoles and Paragraph 2 of "Articles of Association," both in Christoffer Vig's Private Archive. See also Liberman $(1945,136)$. 
23. Less accurate comparisons with areas in Western Europe can be found in the literature. The area mentioned here is a little more than that of Belgium $(30,528$ square kilometres).

24. See, for example, classics such as Zagorsky (1930) and Carr (1958) in Chapter 7.

25. See also GARF Fond 5446, op. 55, d. 1859, pp. 2-63 published in Zagorulko (2005). In addition, see “Agreement," draft by Severoles of 28 June 1929 in GAAO Fond 553, op. 2, d. 1, pp. 12-13 ob. These sources only vaguely touch upon what Sutton (1968) alludes to.

26. An entry of 25 October 1926 in the diary of the head of Russian operations Andreas O. Wager refers to an agreement to pay 29,000 roubles to the Solovetsky Islands prison camp administration. Most likely in a one-off event, internees were in 1926 used in logistics for shipping sawn goods to the Soviet market via Kem. Eventually this also included shipping through Archangelsk. See Jan Wager's Private Archive.

27. See Concession Committee report, GAAO Fond 553, op. 1, d. 3, pp. 30-31. In a heated letter from Prytz to chairman Betchin of 7 March 1927 (National Archives of Norway, Prytz Archive), Prytz states that the problem was solved with the help of Severoles and a three-month loan. A Russian translation of the same letter is found in $R G A E$ Fond 3429, op. 3, d. 1311, pp. 40-70.

28. Krasin is portrayed in Liberman (1945) and in Krasina (1929) by his wife Lyubov. A personal connection dating back to the Genoa conference of April-May 1922 must have led Prytz in the direction of Krasin. This connection is indicated by Prytz's wife Caroline Prytz (1888-1972) in her “Opptegnelser.” See Jon Lundesgaard's Private Archive. 
29. Carr's (1958) Chapter 8 is a useful reference. According to Liberman (1945), in the autumn of 1925, Krasin was hospitalized in Moscow, suffering from leukaemia. On 30 October 1925 his diplomatic mission to Paris came to an end. In a development that would impose additional hardships upon Krasin, he was again appointed to London. According to Liberman, in returning to the West "he resumed none of his old activities.” Krasin died in London on 24 November 1926.

30. See Khromov $(2006,169)$, in which the addressed chairman of the Main Concession Committee was Pyatakov. Pyatakov signed the initial concession contract of Russnorvegoles. At the time he also performed in other important roles, see Graziosi (1991). Trotsky replaced him in May 1925.

31. The abbreviation for this body stands for Vysshii Sovet Narodnogo Khozyaistva ("The Highest Council for the National Economy").

32. Son of the very prominent Norwegian politician and diplomat Paul Benjamin Vogt (1863-1947), Vogt was engaged by Russnorvegoles at the beginning of his working life, between the summer of 1924 until about the end of 1926.

33. One (Saint Petersburg) standard is equal to 4.672 cubic meters. For both shipments, see the report by Prytz of 7 June 1926. For corrected figures, see the board's report of 10 March 1927. Both documents are found in the National Archives of Norway, Prytz Archive.

34. See report to the general assembly of the RFI on 27. January 1928 found at the Norwegian Forest Museum. The output of the Shalakusha mill was set to around 5,000 to 6,000 standards, see report of Prytz to general meeting on 7 June 1926 in the National Archives of Norway, Prytz Archive.

35. Again, see report to the general assembly of 27 January 1928 above, Norwegian Forest Museum. 
36. "Opptegnelser" of Caroline Prytz point in the direction of Quisling being in Moscow at the same time. See Jon Lundesgaard's Private Archive. Dahl (1991, 124) indicates that Schjødt and Quisling must have met. This is interesting because Schjødt later acted as prosecutor in the Quisling trial, which culminated in a death sentence effectuated on 24 October 1945. Avoiding the same fate, Prytz died on 19 February 1945.

37. See pages 23-24 in the letter of 7 March 1927 from Prytz to Betchin in the National Archives of Norway, Prytz Archive.

38. See the protocol of the board of directors of the RFI, National Archives of Norway.

39. See pages 2-4 in report of Prytz to general meeting on 7 June 1926 in the National Archives of Norway, Prytz Archive.

40. See the protocol of the board of directors of the RFI, page 144 from a board meeting of 22 December 1926, National Archives of Norway.

41. See report to the general assembly of the RFI on 27. January 1928 found at the Norwegian Forest Museum.

42. See the board's report of 10 March 1927 in the National Archives of Norway, Prytz Archive.

43. See letter of 7 March 1927 from Prytz to Betchin in two versions. It is difficult to grasp fully how the conflict started out and what lay at its roots. Some Soviet-side perspectives are found in $R G A E$ Fond 3429, op. 3, d. 1311, p. 3.

44. See report of Prytz to general meeting on 7 June 1926 in the National Archives of Norway, Prytz Archive.

45. See Russnorvegoles' board report of 10 March 1927 in the National Archives of Norway, Prytz Archive. 
46. See "Financial Accounts for 1925-1926" in the National Archives of Norway, Prytz Archive.

47. Reichel is an important figure in the available sources, and is occasionally referred to as deputy chairman of the Main Concession Committee.

48. See Goland (1994, 1252-1258).

49. See Quisling's check books in the National Library of Norway. For the first three books, the Gosbank checking account number is 7356, and for the last one 256 .

50. See Section 13 of the concession contract of 5 May 1923 in Christoffer Vig's Private Archive.

51. See documents in the Prytz Archive of the National Archives of Norway.

52. See documents in the Prytz Archive of the National Archives of Norway.

53. Sometime at the beginning of 1927, Lieberman and Vogt started to work together in a trading company in London. Lieberman was managing director, with Vogt as his secretary. The company was chaired by a very prominent naturalized Briton, Sir Karl Knudsen, who was of Norwegian origin.

54. Correspondence in the Prytz Archive indicates that Wm. Brandt's Sons \& Co. and London \& Northern were closely related. That is, Brandt's was most likely the bank of the brothers Schalit and London \& Northern. See letters from Brandt's to Prytz on 28 December 1926, from London \& Northern to Prytz on 8 August 1927 and from Brandt's to London \& Northern on 16 August 1927. All found in the Prytz Archive. Hence, such wheeling and dealing as may have taken place was kept within "the family."

55. See pages 23-24 in the letter of 7 March 1927 from Prytz to Betchin in the National Archives of Norway, Prytz Archive. 
56. The Arcos affair began with British police storming the London premises of the Soviet-controlled trading company Arcos (All-Russian Co-operative Society).

57. See Dahl (1991, 132).

58. Entries in the diary notes of Andreas O. Wager (Jan Wager's Private Archive) conclusively confirm the existence of bonus payments effected by Quisling.

59. See Russnorvegoles' board report to the general meeting on 10 March 1927 (National Archive of Norway, Prytz Archive) stating that "[s]o far no goods have been sold for the inland market."

60. See the protocol of the board of directors of the RFI (National Archives of Norway), page 33 .

61. See documents in the Prytz Archive of the National Archives of Norway.

62. See the protocol of the board of directors of the RFI (National Archives of Norway), page 146.

63. See "Minutes from the board meeting (10 March 1927) and the general meeting (10 March 1927) of Russnorvegoles" in the National Archives of Norway, Prytz Archive.

64. See also Zagorulko $(2005,383)$, which uses sources found in GARF Fond 5446, op. 55 , d. 1855 , p. $11-81$.

65. Evidence in the Prytz Archive at the National Archives of Norway is indirect. That is, in being included in correspondence between London \& Northern and Prytz dated 15 July 1930 and 18 August 1930 (marked posted on 23 September).

66. See minutes, GAAO Fond 553, op. 1, d. 241, pp. 1-2.

67. See GAAO Fond 553, op. 2, d. 8, pp. 3-5. GAAO Fond 553, op. 2, d. 1, pp. 12-13 ob indicates that, sometime in the second half of 1929, Russnorvegoles was dissolved. 
68. An interesting earlier discussion of Quisling's coup plans is given in Fagertun (1996).

References 
Abrahamsen, Egil 2015. Vinter i Seregovo-skogen. Erindringer fra det norske trelasteventyret $i$ Russland [Winter in the Woods of Seregovo: Memoirs from Adventurous Norwegian Ventures in the Russian Timber Business]. Edited by Yngve Astrup \& Jens Petter Nielsen. Stamsund: Orkana. Russian edition (2016): Iz Seregova v Onegu. Vospominaniya o norvezhskom lesnom biznese v Rossii. Archangelsk: Izdatelskiy dom SAFU.

Albin, Adam J. 1989. "Joint Venture Law in the Soviet Union: The 1920s and the 1980s." Northwestern Journal of International Law and Business 9: 633-657.

Astrup, Yngve. 2011. Norske pionerer i Kvitsjфens skogindustri fra 1880 til 1930 [Norwegian Timber Business Pioneers in the White Sea Area from 1880 to 1930]. Elverum: Norwegian Forest Museum. In Russian, published in parallel. Astrup, Yngve 2012. "The Norwegian Sawmill Community by the White Sea." Vuosilusto (Finnish Forest Museum/Finnish Forest History Society) 9 (2012): $48-56$.

Björklund, Jörgen 2000. "Exploiting the Last Phase of the North European Timber Frontier for the International Market 1890-1914: An Economic-Historical Approach.” In Forest History: International Studies on Socio-economic and Forest Ecosystem Change, edited by Mauro Agnoletti \& Steven Anderson, 171-184. Report No. 2 of the IUFRO Task Force on Environmental Change. Wallingford, UK: CABI.

Borgersrud, Lars 2010. Vi er jo et militart parti: Den norske militcerfascismens historie I [After All We Are a Military Party: The History of Norwegian Military Fascism I]. Oslo: Scandinavian Academic Press. 
Butkovsky, Vladimir P. 1928. Inostrannye kontsessii v narodnom khozyaistve SSSR

[Foreign Concessions in the National Economy of the USSR]. Moscow:

Gosizdat.

Carr, Edward H. 1958. A History of Soviet Russia: Socialism in One Country 19241926. Vol. I. New York: Macmillan.

Dahl, Hans Fredrik 1991. Vidkun Quisling - en fører blir til [Vidkun Quisling: A "Führer" is Formed]. Oslo: Aschehoug.

Danishevsky, Karl 1923. “New Attainments.” Severoles. January-February 1923: 7-8. Fagertun, Fredrik 1996. "Rød fare” for Norge revolusjonsfrykt og kamp mot den indre fiende, 1918-1940" [The "Red Threat" in Norway, Fear of Revolution and the Fight Against the Enemy Within 1918-1940]. In Frykt og forventning: Russland og Norge i det 20. århundre [Fear and Expectations: Russia and Norway in the 20th Century], edited by Vladislav I. Goldin \& Jens Petter Nielsen, 63-96. Archangelsk: Arkhangelsk Pomoruniversitetets Forlag.

Fraser, Eugenie (1984). The House by the Dvina: A Russian Childhood. Edinburgh: Mainstream Publishing Company.

Goland, Yurii 1994. "Currency Regulation in the NEP Period.” Europe-Asia Studies 46: $1251-1298$.

Goldin, Vladislav I. 1993. "The Civil War and Allied Intervention in the Russian North (1918-1920): An Analytical Review of Russian Archives.” Acta Borealia 10(1): 19-36.

Goldin, Vladislav I. 2000a. "The Civil War in Northern Russia, 1918-1920.” Acta Borealia 17(2): 65-82.

Goldin, Vladislav I. 2000b. "New Views on the Allied Intervention." Revolutionary Russia 13(1): 88-95. 
Graziosi, Andrea 1991. "Building the First System of State Industry in History: Piatakov's VSNKh and the Crisis of NEP 1923-1926." Cahiers du Monde russe et soviétique 32: 539-580.

Hardy, Henry ed. 2004. Isaiah Berlin: Letters 1928-1946. Cambridge: Cambridge University Press.

Høidal, Oddvar K. 1989. Quisling: A Study in Treason. Oslo: Norwegian University Press.

Jungar, Sune 1974. Skandinaviska företak i Sovjetunionen: Sovjetisk koncessionspolitikk på 1920-tallet [Scandinavian Companies in the Soviet Union: Soviet Concession Policy in the 1920s]. Meddelanden 3. Historiska institutionen, Åbo Akademi.

Khromov, Semen S. 2006. Inostrannye kontsessii v SSSR: Istoricheskii ocherk [Foreign Concessions in the USSR: An Historical Essay]. Documents Part I. Moscow: Institute of Russian History, Russian Academy of Science.

Krasina, Lyubov 1929. Leonid Krassin: His Life and Work. London: Skeffington \& Son.

Kotsonis, Yanni 1992. “Arkhangel'sk, 1918: Regionalism and Populism in the Russian Civil War." Russian Review 51: 526-544.

Liberman, Simon 1945. Building Lenin's Russia. Chicago: University of Chicago Press.

Lieberman, Semyon 1923. "Results of the First Year's Work.” Severoles, JanuaryFebruary 1923: 10.

Lundesgaard, Jon 2015. "NEP Timber Concessions in the1920s: On the Lack of Profitability Problem." In Mezhdunarodnye otnosheniya na evropeiskom severe i v Arktike v pervoi chetverti XX veka: Istoricheskii opyt i sovremennost 
[International Relations in the European North and the Arctic in the First Quarter of the 20th Century: Historical Experience and Today's Situation], edited by Vladislav I. Goldin, 284-295. Archangelsk: Northern Arctic Federal University.

Nielsen, Jens Petter \& Victoria V. Tevlina 2014. "Norsk handel og investeringer i Russland etter 1905” [Norwegian Trade and Investments in Russia after 1905]. In Russland kommer naermere: Norge og Russland 1814-1917 [Russia Comes Closer: Norway and Russia 1814-1917], edited by Jens Petter Nielsen \& Petia Mankova, 482-524. Oslo: Pax Forlag AS.

Nove, Alec 1989. An Economic History of the USSR. 2nd edn. London: Penguin.

Ovsyankin, Evgeny I. 1993. "Russko-norvezhskie obshchestva" [Russian-Norwegian Companies]. Lomonosovets (Archangelsk) 9: 10.

Plessix Gray, Francine du 2005. Them: A Memoir of Parents. New York: Penguin. Prytz, Frederik 1925. Report from the Managing Director Captain Frederik Prytz to the General Meeting of the Russo-Norwegian Onega Wood Co. Ltd. (Russnorvegoles A/S). Delivered in Oslo on 29 May 1925. Marked “Confidential.” Oslo: Fabritius \& Sønner. RA/PA-0749 - Prytz Archive. Repnevskij, Andrej V. 1996. "En ny start: Handelsforhandlingene mellom Russland og Norge 1920-1921 (Et russisk syn)" [A New Start: The Trade Negotiations Between Russia and Norway 1920-1921 (A Russian Point of View)]. In Frykt og forventning: Russland og Norge i det 20. århundre [Fear and Expectations: Russia and Norway in the 20th Century], edited by Vladislav I. Goldin \& Jens Petter Nielsen, 97-120. Archangelsk: Arkhangelsk Pomoruniversitetets Forlag. 
Repnevskij, Andrej V. 1998. SSSR-Norvegiya: Ekonomicheskie otnosheniya mezhvoennogo dvadtsatiletiya [USSR-Norway: Economic Relations during the Nineteen Twenties Between the Wars]. Archangelsk: Pomor State University. Repnevskij, Andrej V. 2010. “Kapitan F. Pryutts - gibkii biznesmen i ... norvezhskii profashist" [Captain F. Prytz - Flexible Businessman and ... Norwegian Profascist]. Vestnik Barents-Tsentra 9: 118-124.

Repnevskij, Andrej V. 2013. "Retsenziya na knigu Ingve Astrupa «Norvezhskie lesopromyshlenniki - pionery osvoeniya russkogo Belomorya 1880-1930»” [Review of Yngve Astrup's “Norwegian Timber Business Pioneers in the White Sea Area from 1880 to 1930"]. Barents-sbornik 1: 191-201.

Repnevskij, Andrej V. and Oksana V. Zaretskaya. 2006. "Kontsessii skandinavov vazhnyi element vosstanovleniya promyshlennosty Russkogo Severa (dvadtsatye gody XX veka)" [Scandinavian Concessions - An Important Element in the Industrial Restoration of the Russian North (the Nineteen Twenties)]. In Evropeiskii Sever v sudbe Rossii. XX vek ( $k$ 80-letiyu professora A.A. Kiseleva) [The European North as Part of Russia. The Twentieth Century (on the 80th Birthday of Professor A. A. Kiselev)], edited by Aleksey V. Voronin, Aleksandr B. Belyaev \& Pavel V. Fedorov, 103-115. Murmansk: Murmansk State Pedagogical University.

Saitzev, Dmitrij M. 1923. "The Forests of the Onega River.” Severoles, JanuaryFebruary 1923: 13-14.

Sogner, Knut 2001. Plankeadel: Kiar og Solbergfamilien under den 2. industrielle revolusjon [Nobility of Sawn Goods: The Kiær and Solberg Families Under the Second Industrial Revolution]. Oslo: Andersen \& Butenschøn. 
Sutton, Antony C. 1968. Western Technology and Soviet Economic Development 1917 to 1930. Stanford: Hoover Institution.

Sølverud, Jørgen 1992. “Spekulanter i jobbetid: En analyse med basis i aksjetegnere i selskapet Russian Forest Industry LTD våren 1917” [Boom-Driven Speculation: An Analysis of Share Subscribers in the Russian Forest Industry Ltd., in Spring 1917]. MA thesis. University of Oslo.

Tevlina, Victoria V. 1994. "Inostrannoe predprinimatelstvo na Evropeiskom Severe Rossii vo vtoroi polovine 19 - nachale 20 vekov (1861-1917)” [Foreign Entrepreneurship in the European North of Russia in the Second Half of the 19th and Beginning of the 20th century (1861-1917)]. PhD dissertation. Petrozavodsk State University.

Vogt, Benjamin 1965. Mennesket Vidkun og forraderen Quisling [The Human Being Vidkun and the Traitor Quisling]. Oslo: Aschehoug.

Vogt, Benjamin 1966. På lykke og fromme: Hendelser og opplevelser frem til 1940 [Life Lived Haphazardly: Incidents and Adventurous Experiences up to 1940]. Oslo: Aschehoug.

Westlie, Bjørn 2015. Fangene som forsvant: NSB og slavearbeiderne på Nordlandsbanen [The Prisoners that Disappeared: Norwegian State Railways and the Slave Workers on the Nordland Line]. Oslo: Spartacus Forlag. Zagorsky, Simon 1930. Wages and Regulation of Conditions of Labour in the USSR. Studies and Reports, Series D (Wages and Hours of Work) 19. Geneva: International Labour Office.

Zagorulko, Maxim M., ed. 2005. Inostrannye kontsessii v SSSR (1920-1930-e gg): Dokumenty i materialy [Foreign Concessions in the USSR (1920s and 1930s): Documents and Materials]. Vol. 2 (Practica i resultatu kontsessiionnoi politiki 
[Practice and Results of Concession Policy]). Moscow: Modern Economy and Law.

\section{Archival Material}

The list is not complete. Smaller documents such as short letters are not included.

These kinds of sources are fully described in the text and notes.

\section{Christoffer Vig, Private Archive}

“Agreement" of 6 June 1922. Understanding between Onega Wood Co. (after the understanding taken over by Altius \& Co. of Amsterdam), Bache \& Vig/Bache \& Wager of Drammen (Norway) and the RFI.

"Articles of Association of the Russo-Norwegian Onega Wood Company Ltd. (Russnorvegoles A/S).” Approbated at the Constituent General Assembly on 11 August 1923.

"Concession Contract" of Russnorvegoles. Unofficial and into Norwegian translated version of the contract of 1923

"Declaration of Intentions" of 21 October 1922. Russian-Western understanding. Referred to in the protocol from the constituent general meeting of Russnorvegoles.

"Protocol from the Constituent General Meeting of Russnorvegoles." Copy of protocol from meeting 11 August 1923.

\section{GAAO/State Archive of the Archangelsk Region}

Agreement between Russnorvegoles and the Government. Draft by Severoles of 28 June 1929, in Fond 553, op. 2, d. 1, pp. 12-13 ob. 
Main Concession Committee report toward the end of 1925. Fond 553, op. 1, d. 3, pp. $30-31$.

Minutes from board meeting on 8 May 1928. Fond 553, op. 1, d. 241, pp. 1-2.

On shares of Russnorvegoles under the control of Severoles. Fond 553, op. 2, d. 8, pp. 3-5 and Fond 553, op. 2, d. 1, pp. 12-13.

GARF/State Archive of the Russian Federation

Document on the organization of concessions. Fond 5446, op. 55, d. 1859, pp. 2-63.

Jan Wager, Private Archive

“Dagboksanteckningar 1926-1929” [Diary notes 1926-1929] of Andreas O. Wager.

Jon Lundesgaard, Private Archive

“Opptegnelser" [Notes] of Caroline Prytz. In 2007 reorganized and in Word brought together versions typewritten in 1978 and 1991 by descendants.

National Archives of Norway, Archive of Union Co. (Norske Skog Union)

"Direktionsprotocol for Russian Forest Industry, Ltd. (Russisk Skogindustri A/S)"

[Protocols of the board of directors of ... ] 1917-1929. RA/PA-

1422/2/A/Ac/L0012/0001. Copy in the archive of the Norwegian Forest

Museum, Elverum.

“Generalforsamlings- og Representantskapsprotokol for Russian Forest Industry, Ltd.

(Russisk Skogindustri A/S)" [Protocols of the general assembly and supervisory 
board of ... ] 1917-1928. RA/PA-1422/2/A/Ac/L0012/0002. Copy in the archive of the Norwegian Forest Museum, Elverum.

National Archives of Norway, Prytz Archive

“Financial Accounts for 1925-1926.” Reports for a year ending with 31 October 1926. RA/PA-0749.

"Report from the Managing Director Captain Frederik Prytz to the General Meeting of the Russo-Norwegian Onega Wood Company Ltd. (Russnorvegoles A/S)" held in Oslo on 7 June 1926 and marked "confidential." RA/PA-0749.

"The Board's Report to the General Meeting of Shareholders of the Russo-Norwegian Onega Wood Company Ltd., March 10th, 1927.” RA/PA-0749.

“To the Chairman of the Board of Russnorvegoles.” Letter by Prytz of 7 March 1927 to chairman Betchin as an answer to his letter of 10 February 1927. RA/PA-0749.

National Library of Norway (Oslo)

“Quisling check books 1926-1929.” Ms. fol. 4096:1:2 (4 russiske sjekkhefter for V. Quisling).

Norwegian Forest Museum (Elverum)

"Beretning til Generalforsamling i Russian Forest Industry Ltd. den 27 januar 1928" [Report to the general assembly of the Russian Forest Industry Ltd, 27 January 1928]. Correspondence and other documents of Elias C. Kiær, ARK-1030.

RGAE/Russian State Archive of the Economy 
Minutes from the board meeting (5 June 1926) and the general meeting (7 June 1926).

Fond 7758, op. 1, d. 73, p. 78-79a.

\section{List of Figures}

Figure 1. Flows-of-currency chart for Russnorvegoles’ Bernheim Blum \& Co. arrangement. 